\title{
Analysis of precast lintel behaviour in AAC masonry walls confined by reinforced lightweight and ordinary concrete
}

\author{
Wojciech Mazur ${ }^{1}$, Tomasz Rybarczyk ${ }^{2}$ \\ ${ }^{1}$ Department of Building Structures; Faculty of Civil Engineering; Silesian University of Technology; \\ Akademicka 2 Street, 44-100 Gliwice, Poland; \\ wojciech.mazur@polsl.pl (DD 0000-0001-6382-1496 \\ ${ }^{2}$ SOLBET Sp. z o.o. Toruńska 71 Street, 86-050 Solec Kujawski, Poland; \\ tomasz.rybarczyk@solbet.pl (iD)0000-0003-1431-9533
}

\begin{abstract}
This paper presents the test results of reinforced precast lintels made of autoclaved aerated concrete (AAC) used to cover window openings in walls made of AAC masonry units. Walls were confined with reinforced lightweight concrete. The two variants of wall confinement with different way of lintel support and the static diagram of a simply supported beam and a constrained beam were tested. Cracks and deformations of test models around window openings were recorded with the Aramis software for non-contact measurements of displacements. Failure of lintels caused the loss of load capacity of test models. Lintels were cracked in the same way, but the sequence of crack formation and their location were different. The test results were compared with the test made for similar walls confined with ordinary concrete. Additional tie-columns did not significantly affected the load capacity of the test models contrary to the walls confined with ordinary concrete.
\end{abstract}

Keywords: autoclaved aerated concrete (AAC), precast lintels, Digital Image Correlation (DIC), confined wall, lightweight concrete

\section{Introduction}

Precast lintels are additional elements in masonry walls in accordance with the standard [1]. Lintels in the wall work with members above them, i.e. masonry units and tie-beams. Reinforced concrete tie-beams can increase the lintel load capacity by about $50 \%$. Due to their stiffness, tie-beams can transfer load from the floor and the masonry wall above, and the lintel is only used as a filler and cover for the opening. Currently, particular importance has been paid to environmentally friendly design and passive buildings with walls that are designed to have the lowest heat transfer coefficient. In extreme cases, reinforced concrete members used in masonry walls create a linear thermal bridge that significantly deteriorates thermal parameters of partition walls. Tie-beams and tie-columns made of lightweight concrete are an alternative that combines 
advantages of concrete and good parameters of thermal insulation. According to the standard [2], lightweight concrete is defined as concrete with a dry density within the range of $800-2000 \mathrm{~kg} / \mathrm{m}^{3}$. Strength characteristics of lightweight concrete are less favourable when compared to ordinary concrete; thus, lintel becomes more significant as it takes greater loads. According to the standard [3], [4], the concrete used for structural purposes should be characterized by the strength class not lower than C12/15. Lightweight concrete can replace mortar to fill toothing when tying precast walls. The effect of the change in the tie beam strength on lintels was verified during tests on full-scale walls confined with reinforced lightweight concrete. The results of this test were compared with those for walls confined with ordinary concrete.

\section{Test models}

Experimental tests described in this paper were performed on two types of confined models with a window opening, which were different in structural aspects (geometry, method of confinement, used concrete). The first group consisted of two series of walls confined with lightweight reinforced concrete. The walls confined along their perimeter marked as MSOL-Z1 (Confined Masonry with an Opening) belonged to the first series. The second series included walls that were confined along their perimeter and had additional tie-beams at vertical edges of a window opening. They were marked as M2SOL-Z1 (Confined Masonry with double confinement and an Opening). Two other test series of the second group included the same wall models as in the first group, in which confining elements were made of ordinary concrete. The third series was marked as MSO-Z1, and the fourth one as M2SO-Z1.

All test models of walls were built from AAC masonry units. Blocks had the width of $180 \mathrm{~mm}$ and the standard compressive strength $f_{\mathrm{b}}$ of $4.0 \mathrm{~N} / \mathrm{mm}^{2}$. They were bonded with readymixed thin-layer mortar with compressive strength $f_{\mathrm{m}}$ of $6.1 \mathrm{~N} / \mathrm{mm}^{2}$. Each block had tongues and grooves on its face, so vertical (head joints) were not filled with mortar.

Two types of concrete were used in the test walls. The first type was lightweight concrete made of foam glass-based aggregate, with the density of $900 \mathrm{~kg} / \mathrm{m}^{3}$ (density class D 1.0 according to [2]) and the mean compressive strength $f_{\text {c.ube }}$ of $10.0 \mathrm{~N} / \mathrm{mm}^{2}$. The second type of concrete was ordinary concrete made of CEM-I 42.5 R cement, with the strength class C20/25. The cross-section of reinforced concrete elements was $180 \times 180 \mathrm{~mm}$, and $180 \times 230 \mathrm{~mm}$ where toothing occurred. The longitudinal reinforcement of confining elements was composed of bars with a diameter of $10 \mathrm{~mm}$, made from steel of the class A IIIN, and the transverse reinforcement contained bars with a diameter of $8 \mathrm{~mm}$. According to EC-6 [4-5], confining elements should have a cross-section of not less than $0.02 \mathrm{~m}^{2}$ with the smallest dimension not smaller than $150 \mathrm{~mm}$ in the wall plane. And the minimum cross-section of longitudinal reinforcement should be $0.8 \%$ of the cross-section of a confining element and not smaller than $200 \mathrm{~mm}^{2}$. The minimum area of the cross-section of longitudinal reinforcement and confining elements in all models was $314 \mathrm{~mm}^{2}$ and $32400 \mathrm{~mm}^{2}$ respectively. 
a)

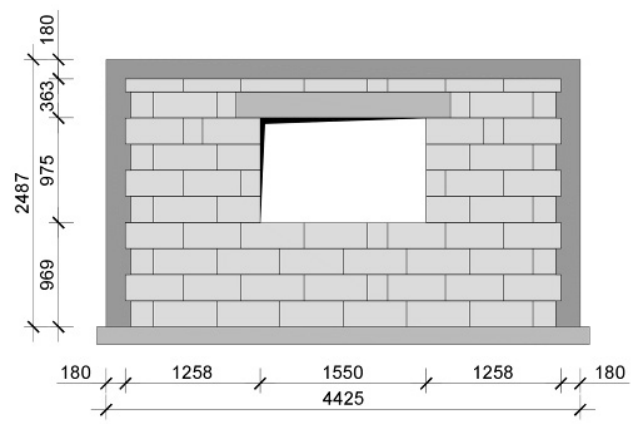

b)

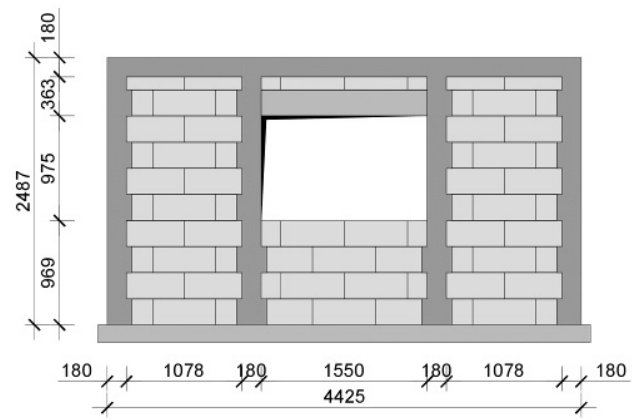

Fig. 1. Models of series: a) MSOL and MSO, b) M2SOL and M2SO. Source: the authors' own study

a)

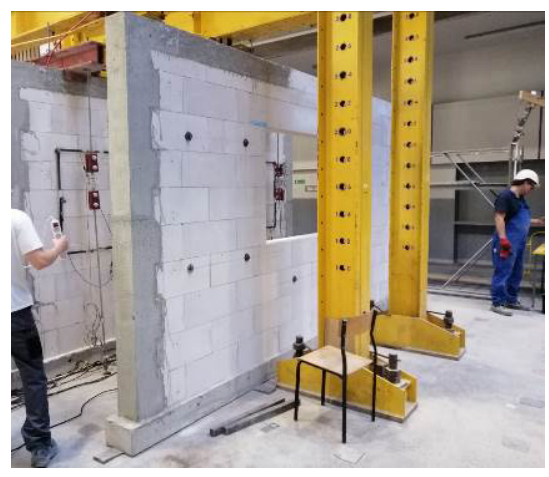

b)

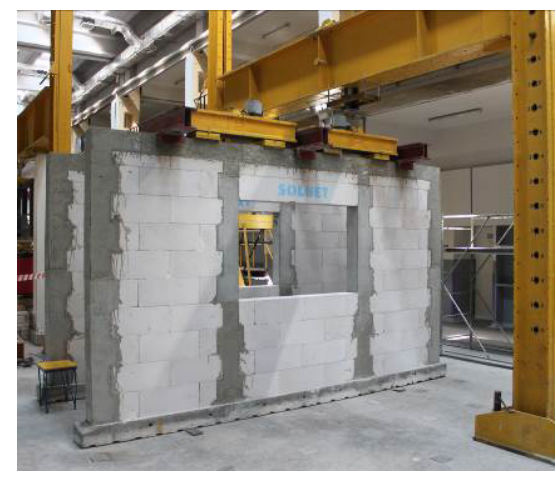

Fig. 2. Models of series: a) MSOL, b) M2SOL. Source: the authors' own study

A centrally placed window opening was $1550 \mathrm{~mm}$ wide and $975 \mathrm{~mm}$ high, which corresponds to the typical width of a window. Reinforced precast lintels made of AAC were used to cover openings. Longitudinal reinforcement of lintels was made of bars with a diameter of $8 \mathrm{~mm}$ (three bottom rebars and two top rebars) welded to open stirrups made of rebars with a diameter of $4.5 \mathrm{~mm}$. Tests on lintels are described in the paper [6]. Only one course of masonry units with a height equal to half of the block height was between the lintel and the tie-beam. Dimensions of the test models are shown in Fig. 1, and their photos in Fig. 2.

\section{Test stand and testing technique}

All the walls were tested at the test stand described in the paper [7]. The test stand and the loading scheme are presented in Fig. 3. 
a)

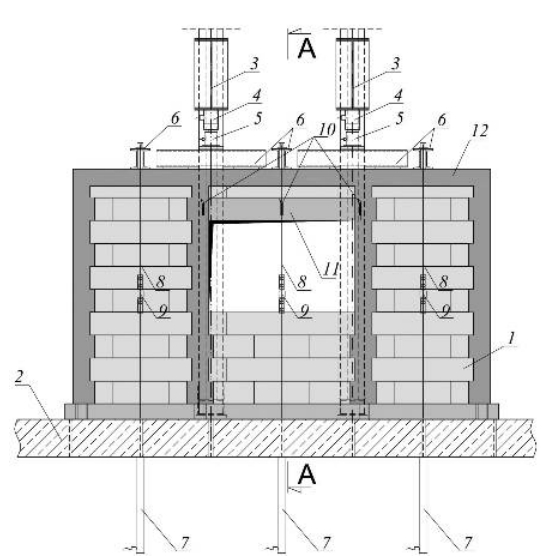

b)

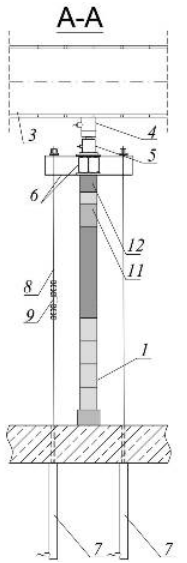

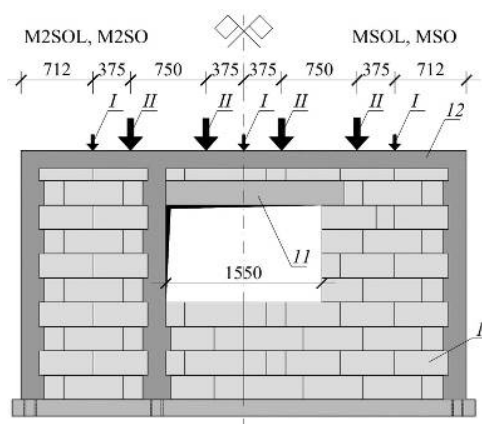

Fig. 3. a) test stand, b) loading scheme. Notations: 1 - AAC masonry units, 2 - reinforced concrete slab, 3 - steel frame, 4 - hydraulic actuator, 5 -dynamometer, 6 - crossbeams, 7 - piston jacks, 8 - steel tendon, 9 - dynamometer, 10 - LVDT, 11 - lintel, 12 - tie-beam and tie-column, $I$ - force caused by piston jacks - auxiliary loading , $I I$ - force caused by hydraulic actuator - a half of main load. Source: the authors' own study

The test models were loaded using two types of loading schemes: the auxiliary and main scheme. Three auxiliary schemes were used. Each of them consisted of two actuators mounted under the floor, on which two test models were placed with two tendons and a crossbeam. The actuators mounted on the steel crossbeam, that was supported on the top surface of the tie beam, were used to apply load to the walls through the tendons. One auxiliary scheme was placed in the middle of the test model, and two others were on both sides at the distance of $1500 \mathrm{~mm}$. Each scheme transferred the load of $50 \mathrm{kN}$ and the minor weight of the crossbeam was neglected. The main loading was induced by two schemes, each of them consisted of a steel frame, the actuator and the crossbeam distributing the load to a pair of forces at the distance of $750 \mathrm{~mm}$.

The area around the window opening in each test model was painted on one side with the irregular high-contrast pattern to record displacements with the Aramis software. Deflections in lintels and strain of the masonry wall observed in other parts of the wall and on its other side were recorded with LVDT sensors connected to the automated test stand for measurements. This paper presents the results only for lintels. The models tested at the test stand are shown in Fig. 4. 
a)

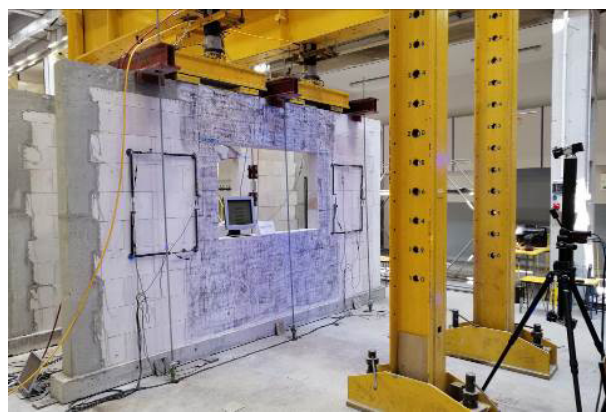

b)

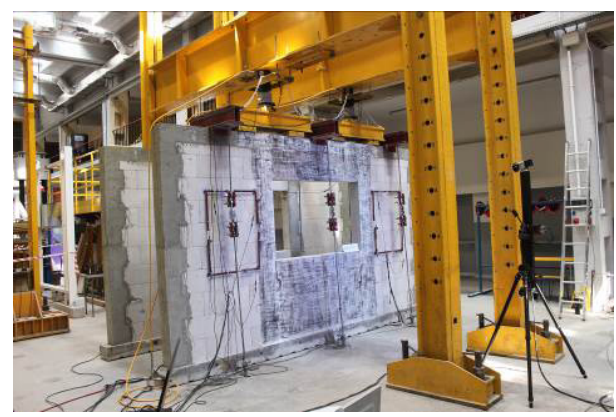

Fig. 4. Models of the following series at the test stand: a) MSOL-Z1, b) M2SOL-Z1. Source: the authors' own study

\section{Test results}

At first the test models were loaded using the auxiliary tendon schemes. Then, the main load was continuously applied until the failure of the model. Images recorded during tests with the Aramis system were processed by GOM Correlate software. Those images were used to determine the development of cracks in the wall around the window opening.

First cracks appeared in the bed joint between the lintel and the masonry units in the models of the series MSOL-Z1. That type of crack was observed in the model MSOL-Z-1-1 under the load of $18.5 \mathrm{kN}$ generated by the auxiliary scheme and at the deflection in the lintel of $0.2 \mathrm{~mm}$ (Fig. 5a). Cracking of the bottom edge of the lintel was noticed under the load of $23.9 \mathrm{kN}$ and at the deflection of $0.5 \mathrm{~mm}$ (Fig. 5b). A further increase in loading produced cracks propagating towards the top edge of the lintel at the support of the wall (Fig. 5c). When the maximum load transferred by the tendon scheme (load of $50 \mathrm{kN}$ ) was reached, deflection in the lintel achieved its limit value $l_{\text {eff }} / 500$. The continuous main loading produced the maximum load of $142.3 \mathrm{kN}$ acting on the lintel, and the lintel deflection of $20.2 \mathrm{~mm}$ (Fig. 5d).

a)

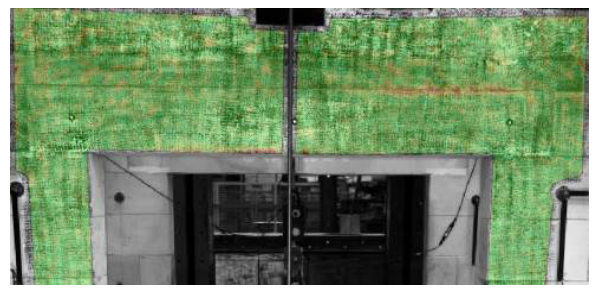

c)

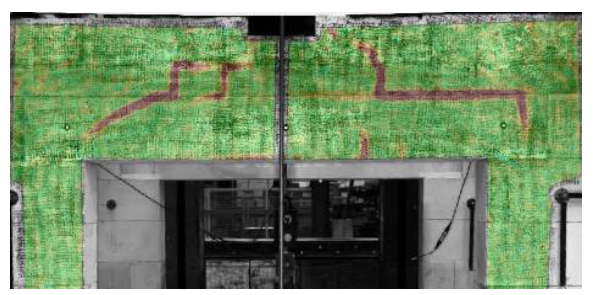

b)

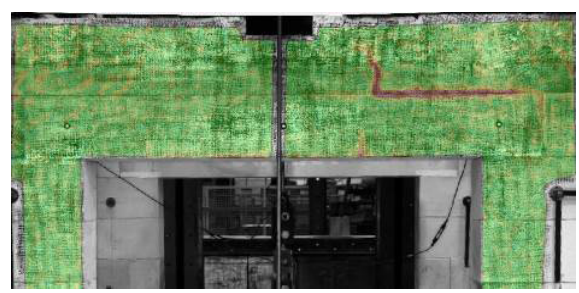

d)

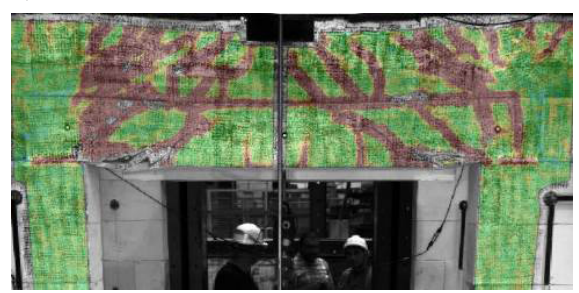

Fig. 5. Crack propagation during tests of the model MSOL-Z1-1. Description in text. Source: the authors' own study 
As in the previous model, the first crack in the model MSOL-Z1-2 was formed in the bed joint under the load of $26.6 \mathrm{kN}$ and at the deflection of $0.4 \mathrm{~mm}$ (Fig. 6a). At a further increase in loading up to $32.7 \mathrm{kN}$ (Fig. 6b), and the corresponding lintel deflection of $0.6 \mathrm{~mm}$, the crack changed into a diagonal crack running to the support edge. Cracking of the bottom edge in the central part of the span was noticed under the load of $35.3 \mathrm{kN}$ and at the deflection of $0.76 \mathrm{~mm}$ (Fig. 6c). The limit load exerted on the lintel was reached under the load of $86.1 \mathrm{kN}$. The maximum load applied to the lintel was $140.0 \mathrm{kN}$, and the corresponding deflection was $17.0 \mathrm{~mm}$ (Fig. 6d).

a)

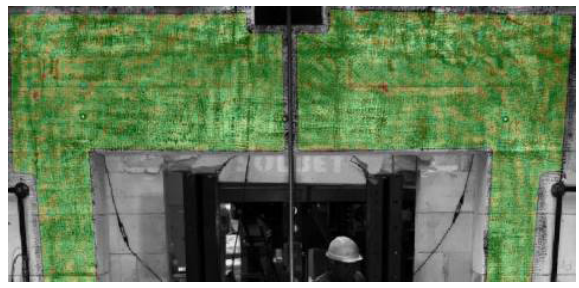

c)

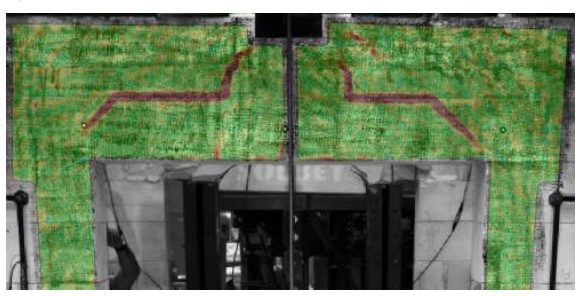

b)

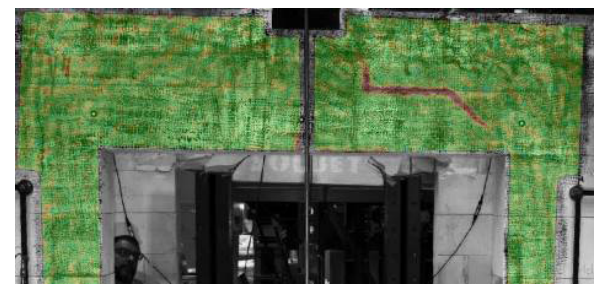

d)

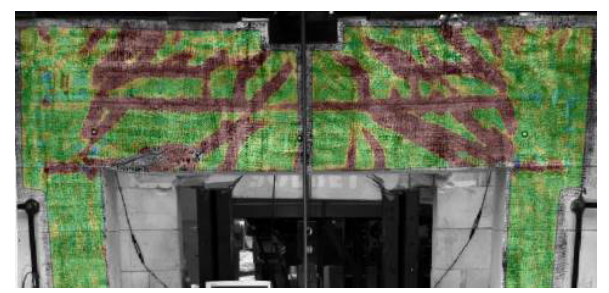

Fig. 6. Crack propagation during tests of the model MSOL-Z1-2. Description in text. Source: the authors' own study

As in the models of the series MSOL-Z1, first cracks in the model M2SOL-Z1-1 with additional confining elements were observed in the bed joint between the lintel and the masonry units. Cracks in the model M2SOL-Z-1-1 were formed under the load of $15.9 \mathrm{kN}$ and at the deflection of $0.25 \mathrm{~mm}$ (Fig. 7a). 
a)

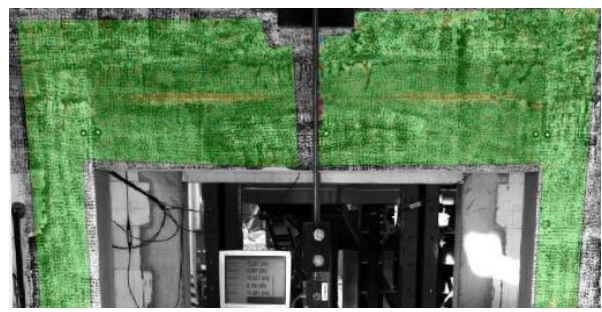

c)

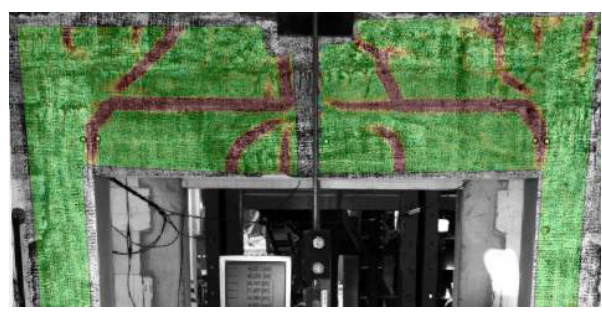

b)

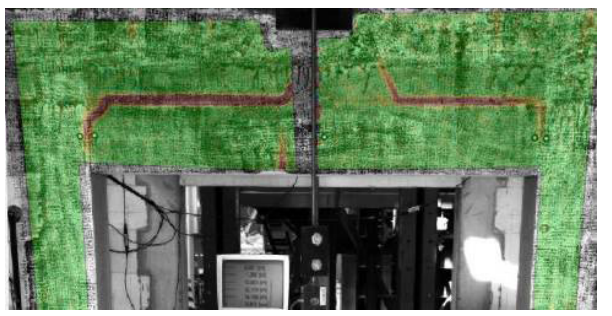

d)

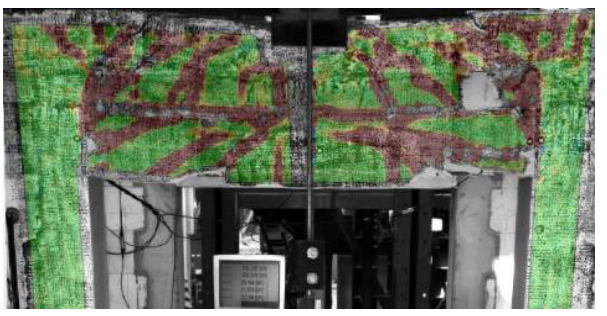

Fig. 7. Crack propagation during tests of the model MSOL-Z1-2. Description in text. Source: the authors' own study

Cracking in the lintel anchorage at the reinforced concrete tie-column occurred under the load increasing up to $23.0 \mathrm{kN}$ and at the deflection of $0.4 \mathrm{~mm}$. A crack in the bottom edge of the lintel was noticed under the load of ca. $24.4 \mathrm{kN}$ and at the deflection of $0.6 \mathrm{~mm}$ (Fig. $7 \mathrm{~b}$ ). The limit deflection of the lintel was reached under the load of $63.1 \mathrm{kN}$ (Fig. 7c). The lintel failure was observed under the load of $142.7 \mathrm{kN}$ and at the deflection of $13.0 \mathrm{~mm}$. A further loading of the model generated even a greater force of $146.0 \mathrm{kN}$ and the lintel deflection of $27.5 \mathrm{~mm}$ (Fig. 7d).

a)

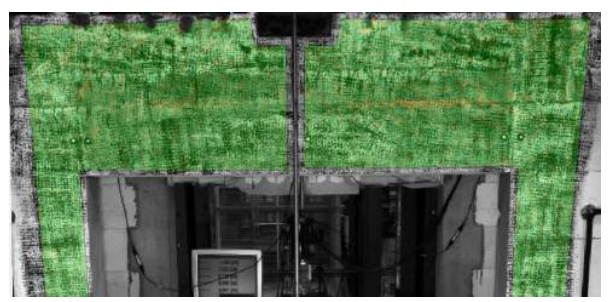

c)

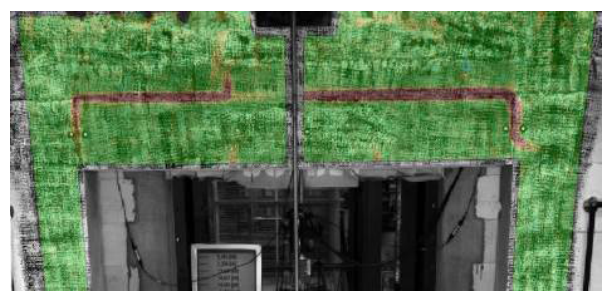

b)

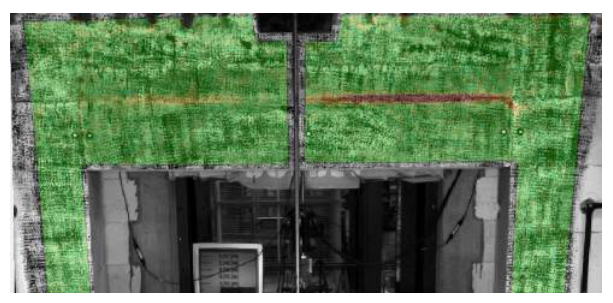

d)

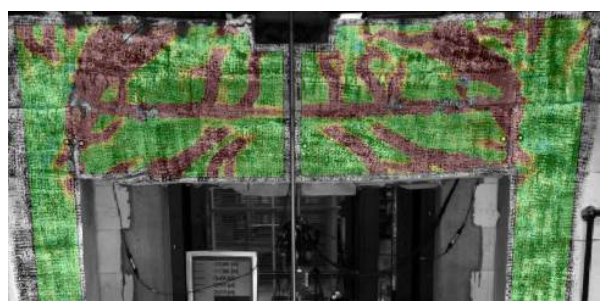

Fig. 8. Crack propagation during tests of the model MSOL-Z1-2. Description in text. Source: the authors' own study 
The cracking scheme for the model M2SOL-Z2 was similar to the first model. Cracking of the bed joint occurred under the load of $18.0 \mathrm{kN}$, and the deflection of $0.2 \mathrm{~mm}$ (Fig. 8a). Cracking of the vertical edge at the junction between the lintel and the reinforced concrete tie column occurred under the load of $18.5 \mathrm{kN}$ and at the deflection of $0.3 \mathrm{~mm}$ (Fig. 8b). The bottom edge of the lintel cracked under the load of $29.5 \mathrm{kN}$ and at the deflection of $0.9 \mathrm{~mm}$ (Fig. 8c). The maximum load exerted on the lintel was $150.6 \mathrm{kN}$ (Fig. 8d), and the corresponding deflection was $15.1 \mathrm{~mm}$. The test was discontinued when the load reached $147.9 \mathrm{kN}$, and the deflection was equal to $27.1 \mathrm{~mm}$.

The models cracked and were destroyed in a similar manner regardless of the type of concrete. A view of final cracks in the models of the series MSOL-Z1 are shown in Fig. 9 and the models of the series M2SOL-Z1 in Fig. 10.

a)

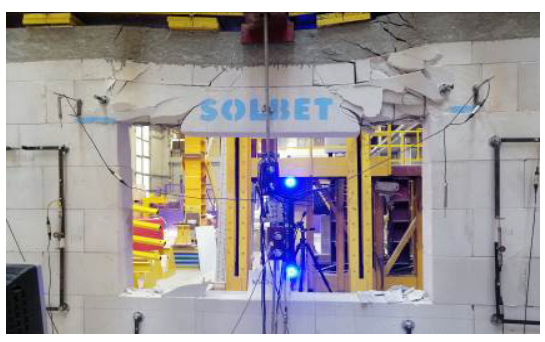

b)

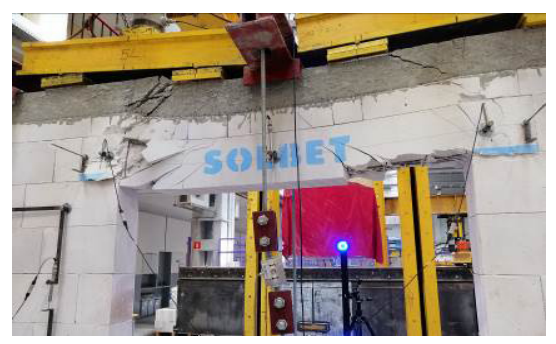

Fig. 9. The upper part of the wall around the window opening in test of the elements of the series MSO-Z1 after tests: a) model 1, b) model 2. Source: the authors' own study

a)

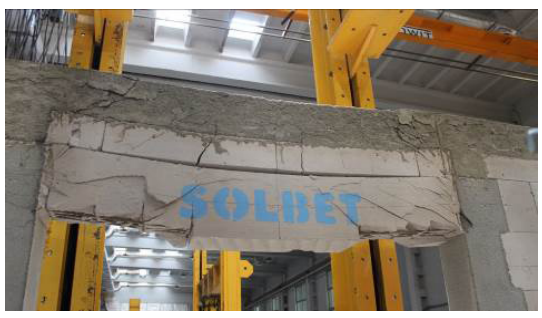

b)

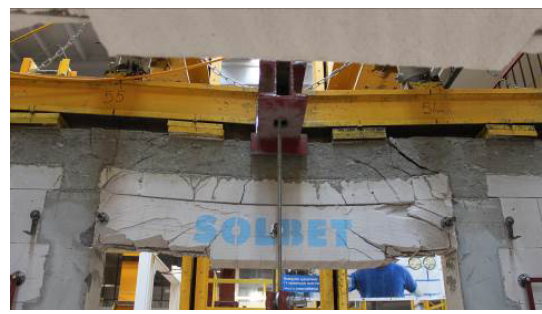

Fig. 10. The upper part of the wall around the window opening in test of elements of the series M2SOL-Z1 after tests: a) model 1, b) model 2. Source: the authors' own study

Table 1. Averaged test results for each series. Source: the authors' own study

\begin{tabular}{llllll}
\hline \multirow{2}{*}{ No. of series } & & $\begin{array}{l}\text { Lintel deflection } \\
\text { at cracking, } \\
\mathrm{mm}\end{array}$ & $\begin{array}{l}\text { Cracking } \\
\text { load } \\
\mathrm{kN}\end{array}$ & $\begin{array}{l}\text { Lintel deflection } \\
\text { at failure, } \\
\mathrm{mm}\end{array}$ & $\begin{array}{l}\text { Maximum } \\
\text { loading, } \\
\mathrm{kN}\end{array}$ \\
\hline \multirow{2}{*}{ MSOL-Z1 } & 1 & 0.5 & 23.9 & 20.2 & 142.3 \\
\hline \multirow{2}{*}{ M2SOL-Z1 } & 2 & 0.6 & 32.7 & 17.0 & 142.0 \\
\hline \multirow{2}{*}{ MSO-Z1 } & 1 & 0.4 & 23.0 & 13.0 & 142.7 \\
\hline \multirow{2}{*}{ M2SO-Z1 } & 1 & 0.3 & 18.5 & 15.1 & 150.6 \\
\hline
\end{tabular}


Table 1 compares the test results for the walls confined with ordinary and lightweight concrete. There are load values resulting in cracking of the lintel, the maximum values, and the corresponding deflection in the lintel.

\section{Analysis of test results}

Destructive forces acting on both models of the series MSOL-Z1 were nearly the same, and the average value was $142.1 \mathrm{kN}$. For the wall models with additional confinement, the destructive forces differed by as little as $8 \mathrm{kN}$, and their average value was approx. $146.7 \mathrm{kN}$. The destructive force exerted on the models confined along their perimeter by lightweight concrete was lower by only $3 \%$ when compared to the models with additional confinement. This difference was $19 \%$ in the case of similar models confined by ordinary concrete. The failure of the models of the series MSOL-Z1 was found under the load corresponding to $66 \%$ and $54 \%$ of the failure load for the models of the series MSO-Z1 and M2SO-Z1 respectively. For the models of the series M2SOL-Z1, the failure load corresponded to $66 \%$ and $55 \%$ of the destructive force acting on the models of the series M2SO-Z1 and MSO-Z1 confined with ordinary concrete. The relation between deflection of the lintel and its loading for all experimental models is illustrated in Fig. 11.

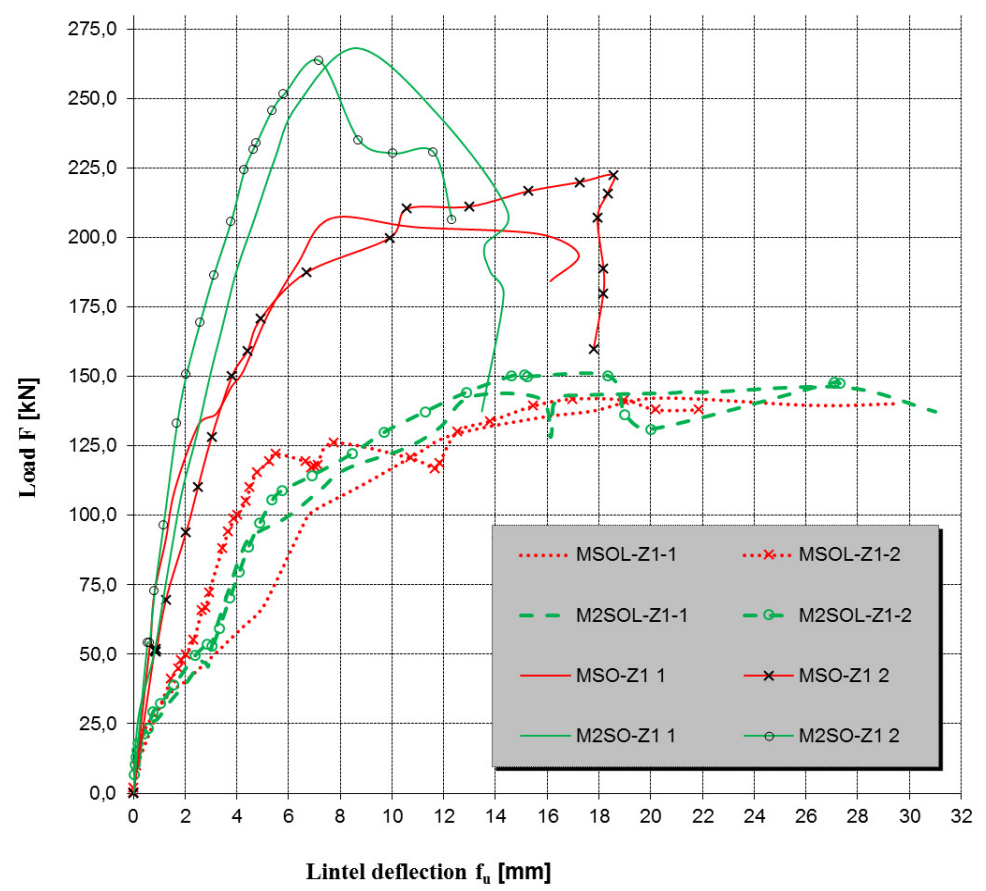

Fig. 11. Load $F_{\mathrm{y}}-$ lintel deflection $f_{\mathrm{y}}$ relationships in models with confined walls. Source: the authors' own study

The morphology of cracks in each model of walls indicated that cracks were at first developed in the bed joint between the lintel and the wall. Then, they appeared in the models of the series M2SOL-Z1 with fixed lintels, at the junction of lintels and reinforced concrete tie-columns, and then in the bottom centre of the lintel. When the bed joints were cracked in 
the models MSOL-Z1, diagonal cracks running from the upper edge of the lintel were observed at first. Then cracks developed in the bottom centre of the beam. The reverse sequence of crack formation is also possible. Such scheme suggests a significant impact of the beam over the support, which is neglected in calculations of the load capacity of the lintel and in the reinforcement structure.

Assuming that the wall structure should transfer the load from one floor with the span of $6.0 \mathrm{~m}$, which was represented in the tests by the tendon scheme generating the load, first cracks in the lintels were observed under the load corresponding to $37-65 \%$ of the load applied by the floor. At the time of lintel cracking, the deflections were about $10-20 \%$ of the limit deflection $l_{\text {eff }} / 500$ equal to $3.3 \mathrm{~mm}$.

The analysis of relations between the load and the lintel deflection in the models confined by lightweight concrete indicated there was no sudden drop in the load after reaching the maximum load in contrast to confined models of the series M2SO-Z1.

\section{Conclusions}

The discussed results of the tests show that, like in the performed tests [8], the most stressed zone of the lintel is its support and ends, and not the central zone which often tends to be considered as the only and most important zone for engineering calculations for lintels. The standardized test of lintels [9] in the scheme of simply supported beam does not represent the behaviour of lintels in the wall, but only during assembly.

The use of additional reinforced lightweight concrete tie-columns along the vertical edges of the window opening in the models confined by lightweight concrete caused an increase in the maximum lintel load by $3 \%$. In the case of the similar wall models confined by ordinary concrete, the reinforced concrete tie-columns increased the load capacity of the walls by $19 \%$. The tests should be repeated on lightweight concrete with a compressive strength of not less than $15 \mathrm{~N} / \mathrm{mm}^{2}$ to ensure that walls meet standard conditions [3], [4], [10].

\section{References}

[1] 845-2:2013-10 PN-EN: Specification for ancillary components for masonry. Part 2: Lintels.

[2] PN-EN 206+A1:2016-12 Concrete. Specification, performance, production and conformity.

[3] PN-EN 1992 -1-1: Eurocode 2 - Design of concrete structures - Part 1-1: General rules and rules for buildings

[4] PN EN 1996-1-1: Eurocode 6: Design of masonry structures - Part 1-1: General rules for reinforced and unrein-forced masonry structures

[5] Drobiec Ł., Jasiński R., Piekarczyk A., Konstrukcje murowe wedtug Eurokodu 6 i norm zwiąanych, vol. 1. Wydawnictwo PWN, Warszawa 2013.

[6] Mazur W., Drobiec Ł., Jasiński R., "Research of Light Concrete Precast Lintels", Procedia Engineering, vol. 161, 2016, pp. 611-617. https://doi.org/10.1016/j.proeng.2016.08.711

[7] Drobiec Ł., Jasiński R., Mazur W., "Analysis of AAC precast lintels embedded in walls different construction", ce papers. 2018;2:367-376. https://doi.org/10.1002/cepa.830

[8] Mazur W., Drobiec Ł., Jasiński R., "Research and numerical investigation of masonry - AAC precast lintels interaction”, Procedia Engineering, vol. 193, 2017, pp. 385-392. https://doi. org/10.1016/j.proeng.2017.06.228 
[9] PN-EN 1356:1999 Performance test for prefabricated reinforced components under transversal load of autoclaved aerated concrete or lightweight aggregate concrete with open structure

[10] Rybarczyk T., Drobiec Ł., Jasiński R., Jonderko K., "Ustalenia normowe, praktyczne aplikacje i wybrane badania murowych ścian z elementów murowych z ABK skrępowanych żelbetem", in XXXIII Ogólnopolskie Warsztaty Pracy Projektanta Konstrukcji. Szczyrk 6-9 marca 2018 r., vol. 4, pp. 85-107. 
